\title{
Factors Determining Rice Farm Households' Adoption of Organic Farming in Taiwan
}

\author{
Min-Han Tsai, Yun-Cih Chang, Ting-Ya Yang and Yir-Hueih Luh *D \\ Department of Agriculture Economics, National Taiwan University, Taipei 10617, Taiwan; \\ d08627001@ntu.edu.tw (M.-H.T.); f08627010@ntu.edu.tw (Y.-C.C.); r08627001@ntu.edu.tw (T.-Y.Y.) \\ * Correspondence: yirhueihluh@ntu.edu.tw
}

Citation: Tsai, M.-H.; Chang, Y.-C.;

Yang, T.-Y.; Luh, Y.-H. Factors

Determining Rice Farm Households'

Adoption of Organic Farming in

Taiwan. Agronomy 2021, 11, 2195.

https://doi.org/10.3390/

agronomy11112195

Academic Editor: Peter J. Batt

Received: 30 September 2021

Accepted: 26 October 2021

Published: 30 October 2021

Publisher's Note: MDPI stays neutral with regard to jurisdictional claims in published maps and institutional affiliations.

Copyright: (c) 2021 by the authors. Licensee MDPI, Basel, Switzerland. This article is an open access article distributed under the terms and conditions of the Creative Commons Attribution (CC BY) license (https:// creativecommons.org/licenses/by/ $4.0 /)$.

\begin{abstract}
The adoption of environmentally friendly farming practices, such as organic farming, is promoted as a promising option for meeting the sustainable development goals in Taiwan. Taking the paddy rice as an example, this study examines the determining factors of organic farming adoption with an emphasis on farm households' socio-economic characteristics. Based on data drawn from the 2015 Census of Agriculture, Forestry, Fishery and Animal Husbandry, rice farm households' adoption of organic farming is defined as allocating part of the farmland to rice plantation without using any chemical fertilizers and pesticides. In line with previous research, farm operators' age, educational level and on-farm workdays are found to be significant determinants of organic farming adoption. Socio-economic characteristics of the farm household are also found to be relevant to the adoption decision. The results suggest that household-level human capital such as proportion of middle-aged or elder members, and proportion of members with college degree, have significantly positive effect on the adoption probability. Since organic farming is more labor-demanding than conventional farming, this study performs a further analysis to examine the differences in the determining factors between full-time and part-time households. Relative to the young operators, middle-aged operators in the full-time households are found to be less likely to adopt organic farming, whereas the elder operators in the part-time households have a higher adoption probability. Additionally, share of members with a college degree is found to be another significant driving factor of adoption, which is however only true for the part-time households. Exploring the diverse impacts of socio-economic factors for the two groups of households contributes to the extant literature by narrowing the gap in understanding the relation between farm management strategy and organic farming adoption.
\end{abstract}

Keywords: organic farming; adoption determinants; rice farm households; household-level characteristics; human-capital related factors; agriculture census data

\section{Introduction}

With the increasing awareness of negative impacts of chemical fertilizers and pesticides on the environment, environmentally-friendly farming practices have been proposed as promising alternatives for the achievement of sustainable development goals. One major thread of research in the past has focused on the identification of the drivers and/or barriers influencing the adoption rate of organic farming. The extant literature on the determining factors of the adoption of organic farming can be roughly divided into four categories including: (1) farmers' socio-economic characteristics; (2) farm characteristics; (3) attitudinal or psychological factors; and (4) social capital and learning. A similar categorization of the evidence-based factors affecting farmers' organic farming adoption decision can be found in the most recent reviews, e.g., [1].

Farmers' socio-economic characteristics identified as the factors influencing the adoption of organic farming include the farmer's gender, age and education, [1-12]. It was found that female farmers are more inclined to adopting organic farming $[1,2,5,7,9,10]$. Possible explanations for the significant gender differences in practicing organic agriculture 
may be due to different value orientations held by females and males [13] and the fact that females' bond with Nature is inherently stronger than that of males [14]. Another major determinant of organic farming adoption is the age of the farmer. Some of the previous studies found that younger farmers are more likely to adopt organic farming [2,5,7,9]. However, in some recent reviews of the factor influencing sustainable farming practices adoption in Europe, age is found to be of importance in terms of affecting the adoption of sustainable farming practices but the empirical evidence is not conclusive as to if age is a driver or barrier [12]. A similar finding was reported in a study of organic cotton which found old farmers are more likely adopt organic farming [10]. In addition to gender and age, some of the previous studies found education to play a role in influencing the adoption of organic farming. Most of the extant research found the probability of organic farming adoption is higher for farmers with higher educational levels, e.g., [4,5,8]. The two recent review articles, [1,12], also suggested the same conclusion after a systematic review. However, in some study of West Africa, farmers with lower educational levels were found be more inclined to adopting organic cotton farming practices [10], while the effect of education was found to be insignificant in explaining the adoption of organic horticultural techniques in the UK [3].

Taking the paddy rice as an example, this study examines the determining factors of organic farming adoption in Taiwan. Organic farming has been the major environmentallyfriendly farming practice adopted in Taiwan since it was first promoted in 1995 [15]. However, the share of farmland allocated to organic agriculture is still below $2 \%$ (Figure 1). The findings in this study can provide important policy implications concerning the promotion and development of the environmentally-friendly farming practices in Taiwan. Furthermore, with an emphasis on farm households' socio-economic characteristics that are related to human capital, this study departs from the previous research by investigating the effect of farm-household-level human capital on the adoption of organic farming. Based on 213,534 rice farm households drawn from the 2015 Census of Agriculture, Forestry, Fishery and Animal Husbandry (henceforth 2015 agriculture census in short), shares of different age groups and educational levels in the household working population, that is, members aged 15 and above, are used to capture the effect of farm-household characteristics. This study contributes to the existing body of knowledge by advancing our understanding of the factors determining the adoption of the environmentally-friendly farming practices.

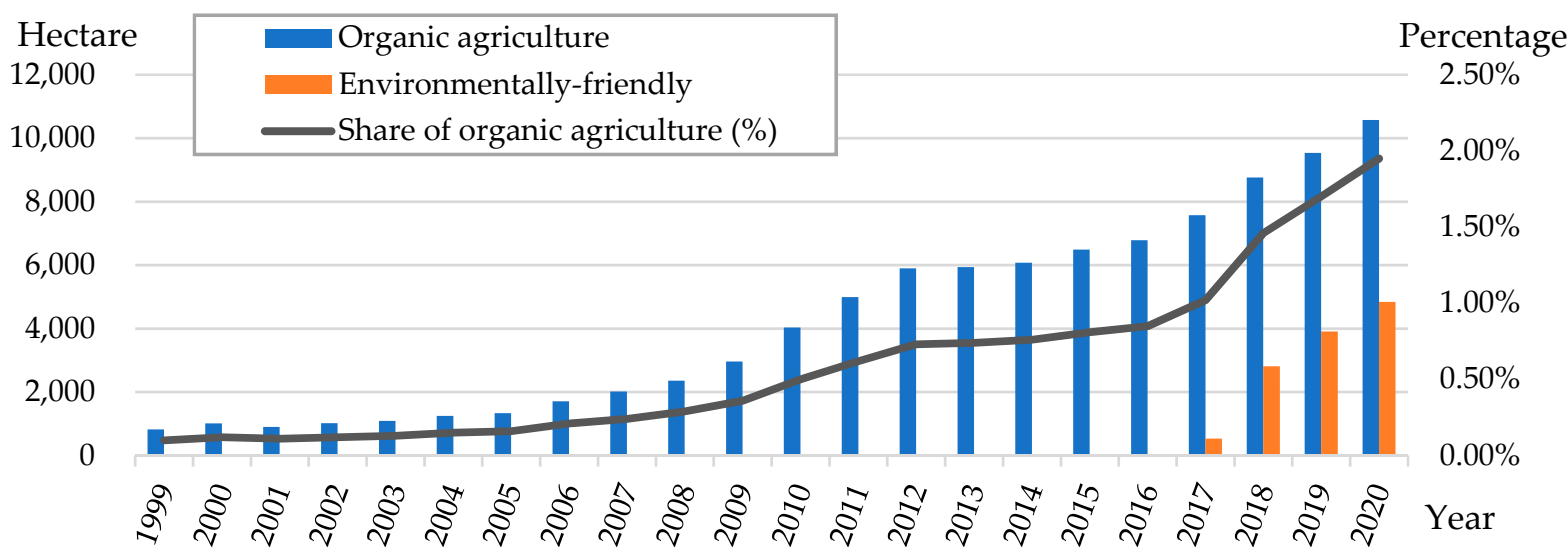

Figure 1. Land area and share of organic agriculture in Taiwan. Source: Adapted from [16], with permission from Organic Agriculture Promotion Center (OAPC), 2021. OAPC official website: www.oapc.org.tw.

The possible influence of off-farm work on the adoption of organic farming has been discussed in the literature of technology adoption [17,18] and organic farming [19]. Some study of Spanish olive orchards showed that organic olive farmers tend to work off the farm [19]. Nonetheless, another study for U.S. soybean farmers pointed out that farmers having off-farm works may become reluctant to adopt managerially intensive technology [20]. Since organic farming is often considered as more labor-demanding than 
conventional farming, the two divergent findings motivate our further investigation of differences in the factors determining the adoption decision between full-time and parttime farmers. Exploring the differences in the adoption behavior between the two types of farmers can contribute to the extant literature by narrowing the gap in understanding the association of farm management strategy and the adoption behavior.

\section{Materials and Methods}

\subsection{Data and Descriptive Statistics}

The rice farm household data used in the present study is taken from the 2015 agriculture census which is a national survey released by the Executive Yuen in Taiwan. According to the codebook of the agriculture census data, the "main crop" is defined as the crop which contributes most to the total production value in each farm household. We only focused on farm households mainly producing paddy rice which is composed of around $39 \%$ of all farm households in the 2015 agriculture census, resulting in 213,534 observations in total.

Definitions and descriptive statistics of the dependent and explanatory variables are listed in Table 1. The boldface subtitles (Dependent variable, Principal operator, Household members over 15 years old, and Farm characteristics) are used to emphasize different types of the explanatory variables. The rice farm households' adoption of organic farming is defined as allocating part of the farmland to rice plantation without using any chemical fertilizers and pesticides. A positive share of farmland devoted to organic farming is used as the indicator for the adoption of organic farming. Among the 213,534 rice farm households, approximately $4 \%$ of the households allocate part of their farmland to organic farming.

Table 1. Definition and descriptive statistics.

\begin{tabular}{|c|c|c|c|}
\hline Variable & Definition & Mean & Frequency \\
\hline \multicolumn{4}{|l|}{ Dependent variable } \\
\hline Adopt & Organic rice farming is adopted $=1$ and 0 otherwise & 0.039 & 8246 \\
\hline \multicolumn{4}{|l|}{ Principal operator } \\
\hline Male & Gender of the principal operator & 0.811 & 173,162 \\
\hline Age (under 45) & Age (less than 45 years old) & 0.048 & 10,268 \\
\hline Age (45-65) & Age (45-64 years old) & 0.455 & 97,130 \\
\hline Age (65 and up) & Age (more than 64 years old) & 0.497 & 106,136 \\
\hline Elementary & Education (elementary school and below) & 0.485 & 103,524 \\
\hline Junior & Education (junior high school) & 0.213 & 45,418 \\
\hline Senior & Education (senior high school) & 0.222 & 47,389 \\
\hline College & Education (college and above) & 0.081 & 17,203 \\
\hline On-farm work (<30 days) & On-farm work (less than 30 days) & 0.268 & 57,331 \\
\hline On-farm work (30-59 days) & On-farm work (30-59 days) & 0.302 & 64,413 \\
\hline On-farm work (60-89 days) & On-farm work (60-89 days) & 0.223 & 47,682 \\
\hline On-farm work (90-149 days) & On-farm work (90-149 days) & 0.121 & 25,835 \\
\hline On-farm work (150-179 days) & On-farm work (150-179 days) & 0.048 & 10,193 \\
\hline On-farm work (180-249 days) & On-farm work (180-249 days) & 0.023 & 4936 \\
\hline On-farm work (>249 days) & On-farm work (more than 249 days) & 0.015 & 3144 \\
\hline Variable & Definition & Mean & Std. Dev. \\
\hline \multicolumn{4}{|c|}{ Household members over 15 years old } \\
\hline FH_male & Share of male members & 0.557 & 0.25 \\
\hline FH_age (under 45) & Share of members under 45 years old & 0.330 & 0.29 \\
\hline FH_age (45-65) & Share of members aged 45 to 64 & 0.343 & 0.30 \\
\hline FH_age (65 and up) & Share of members aged 65 and up & 0.327 & 0.35 \\
\hline FH_elementary & Share of members with elementary school education and below & 0.339 & 0.34 \\
\hline$\overline{\mathrm{FH}}$ _junior & Share of members with junior high school education & 0.160 & 0.26 \\
\hline FH_senior & Share of members with senior high school education & 0.270 & 0.30 \\
\hline FH_college & Share of members with college education and below & 0.231 & 0.28 \\
\hline Working & Share of members currently working & 0.762 & 0.25 \\
\hline Not working & $\begin{array}{l}\text { Share of members not working (housework, students, sick, } \\
\text { retirement, etc.) }\end{array}$ & 0.238 & 0.25 \\
\hline \multicolumn{4}{|l|}{ Farm characteristics } \\
\hline Land & Farmland used for crop production (hectare) & 0.719 & 1.52 \\
\hline Labor & Hired labor (calculated by number of labors hired per month) & 0.757 & 3.44 \\
\hline
\end{tabular}


The farm operators are categorized into three age groups: (1) young farmers (less than 45 years old); (2) middle-aged farmers (45-64 years old) and (3) elder farmers (more than 65 years old). According to the descriptive statistics reported in Table 1, the principal operators are mostly male, in old group over 65, and had education level below junior high school. We divide working days on the farm into seven groups. The operator's on-farm working day could be also used to determine whether it was a full-time or part-time farm household. Full-time farms are those whose operator's on-farm working days are more than 150 days [21]. As the data shown in Table 1, full-time farms only account for $8.6 \%$.

In the present analysis, the socio-economic characteristics of family members over 15 years old are taken into account. The household-level factors considered include the proportion of each educational level, working status, gender, and age group. The average education level of the farm household is usually higher than that of the operator. According to Table 1, the farm household's gender and age distributions are more equally distributed.

There are two farm-level determinants considered in this study-farmland area and number of hired workers. The sample mean of farmland (in hectare) and hired workers (in persons) are, respectively, 0.719 and 0.757 . To check the distribution of farm land and hired labor, Figure 2 shows the scatter plot with labor on x-axis and land on y-axis. The summary statistics indicate that the distributions of both farmland and worker are skewed to the right.

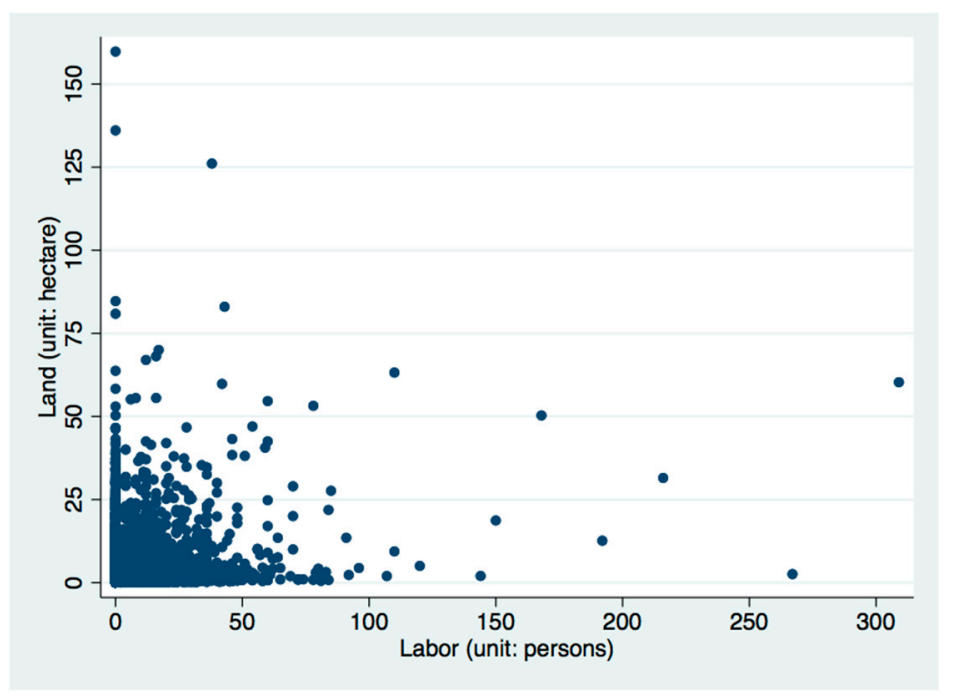

Figure 2. Scatter plot with labor and land.

\subsection{The Model}

The adoption of organic farming can be described using a random utility model (RUM). The adoption choice lies in the mutually exclusive and exhaustive choice set, $J$, in which $j=0$ stands for conventional farming whereas $j=1$ stands for organic farming. The utility resulting from individual $i^{\prime} s$ adoption of farming method $j$ is denoted by $U_{i j}$, which is specified as the following [22,23]:

$$
U_{i j}=V_{i j}\left(\mathbf{X}_{i} ; \boldsymbol{\beta}_{j}\right)-\epsilon_{i j}, i=1,2, \ldots, N, j=0,1
$$

To put it simply, let $V_{i j}$ stands for $V_{i j}(\cdot)$. In (1), $V_{i j}$ is the expected utility which is assumed to be a function of all observable attributes, denoted by $\mathbf{X}_{i}$. Vector of parameters is denoted by $\boldsymbol{\beta}_{i j}$, and the random error term is denoted by $\epsilon_{i j}$. The probability farmer $i$ deciding to adopt organic farming can therefore be written as:

$$
\operatorname{Prob}\left(U_{i 1}>U_{i 0}\right)=\operatorname{Prob}\left(V_{i 1}-\epsilon_{i 1}>V_{i 0}-\epsilon_{i 0}\right)=\operatorname{Prob}\left(V_{i 1}-V_{i 0}>\epsilon_{i 1}-\epsilon_{i 0}\right)
$$


The probability of adoption is, therefore, equal to the cumulative probability of $\epsilon_{i}$ on the right-hand side in (2). In this study, we use the probit model to estimate the factors influencing the rice farm households' decision to adopt organic farming. Accordingly, the error term is assumed to follow the standard normal distribution.

The observed choice of adoption of organic farming can be denoted by some indicator variable, $y$, which takes the value of 1 if the farm household allocates part of its farmland to organic farming and takes the value of 0 if otherwise. The model is formulated as the following:

$$
\begin{gathered}
y_{i}^{*}=\beta_{0}+\mathbf{X}_{i 1} \boldsymbol{\beta}_{1}+\mathbf{X}_{i 2} \boldsymbol{\beta}_{2}+\mathbf{X}_{i 3} \boldsymbol{\beta}_{3}+e_{i} \\
\operatorname{Prob}\left(y_{i}^{*}>0 \mid \mathbf{X}_{1}, \mathbf{X}_{2}, \mathbf{X}_{3}, \boldsymbol{\beta}_{0}, \boldsymbol{\beta}_{1}, \boldsymbol{\beta}_{2}, \boldsymbol{\beta}_{3}\right)=\Phi(\mathbf{X} \boldsymbol{\beta})=\int_{-\infty}^{\mathbf{X} \boldsymbol{\beta}} \phi\left(e_{i}\right) d e_{i}
\end{gathered}
$$

In the above equations, the latent variable, $y_{i}{ }^{*}$, is a linear function of $\mathbf{X}_{1}, \mathbf{X}_{2}$ and $\mathbf{X}_{3}$. $\mathbf{X}_{1}, \mathbf{X}_{2}$ and $\mathbf{X}_{3}$ denote, respectively, the vectors of the socio-economic characteristics of the farm operator, farm household and farm. $\beta_{1}, \beta_{2}$ and $\beta_{3}$ are the parameter vectors corresponding to $\mathbf{X}_{1}, \mathbf{X}_{2}$ and $\mathbf{X}_{3}$. The adoption probability is an integral over a range of the values of the error term $e_{i}$. Considering that there might be nonlinear effect in land size, its quadratic term was included in the model.

The probit model is estimated by the maximum likelihood (ML) method. The coefficients estimated therefore have different meaning compared with those in linear regression models. To obtain more straightforward results, we provide partial marginal effect estimated at means. Further discussion about the probit model can be found in [23].

$$
\frac{\partial E(y \mid \mathbf{X}, \boldsymbol{\beta})}{\partial \mathbf{X}}=\phi(\mathbf{X} \boldsymbol{\beta}) \boldsymbol{\beta}
$$

\section{Results}

\subsection{Determinants of Adoption}

Our primary interest is in identifying the determinants of organic farming adoption. To this end, results of probit estimation are reported in Table 2. Since the coefficient estimates in the probit model is not a measure of the marginal effect of the explanatory variables, we also report the marginal effect estimates in Table 2.

Results in Table 2 indicate that the principal operator's age is one significant determinant of organic farming adoption. Relative to the young farmers, elder farmers that aged 65 years old or older are more likely to adopt organic farming. In addition to age, educational level is another human capital related factor. The marginal effect estimates for the principal operator having a college degree is 0.013 , suggesting that operators that are well-educated have approximately $1.3 \%$ higher probability of organic farming adoption. The on-farm working days have positive effects on the adoption of organic farming. In general, farmers devoting more time on the farm have higher probability to adopt organic farming. The marginal effects range from $1.14 \%$ to $31.8 \%$, with a slight decline to $13.3 \%$ for the group with on-farm working days between 180-249 days. Farms with more hired workers also tend to adopt organic farming, with $0.1 \%$ higher in the probability of adoption. The result also indicates the influential role of educational level. It is found that, relative to operators receiving elementary school education, the principal operator holding a college degree or above are more inclined to adopting organic farming.

Socio-economic characteristics of the farm household are found to be relevant to the adoption behavior. Farm households with higher proportion of middle-aged or elder members (age $\geq 65$ ) have significantly higher probability to adopt organic farming. Specifically, more of the middle-aged and elder members in the farm household increases the probability of adoption by $1.4 \%$ and $1.3 \%$ respectively. Proportion of farm household members with college degree is an indication of household-level of human capital. Results in Table 2 indicate farm households with more members attaining the college degree have approximately $1.5 \%$ higher adoption probability. The result therefore provide evidence 
supporting the positive influence of household-level human capital on the adoption of the environmentally-friendly farming practices.

This study considers two farm factors in explaining rice farm household's adoption behavior. With a marginal effect estimate of 0.001 , the result in Table 2 indicates the positive effect of the number of hired labor on the adoption probability. Considering possible nonlinear influences of farmland area, the squared term of farmland is included into our regression model.

Table 2. Coefficient estimates and marginal effect.

\begin{tabular}{|c|c|c|c|c|c|c|}
\hline \multirow[b]{2}{*}{ Variable } & \multicolumn{3}{|c|}{ Probit Regression } & \multicolumn{3}{|c|}{ Marginal Effect } \\
\hline & Coef. & & Std. Err. & $\mathrm{dy} / \mathrm{d} x$ & & Std. Err. \\
\hline \multicolumn{7}{|l|}{ Principal operator } \\
\hline Male & -0.028 & & 0.022 & -0.002 & & 0.002 \\
\hline Age (45-65) & -0.003 & & 0.034 & 0.000 & & 0.003 \\
\hline Age (65 and up) & 0.061 & * & 0.036 & 0.005 & * & 0.003 \\
\hline Junior & -0.005 & & 0.028 & 0.000 & & 0.002 \\
\hline Senior & 0.050 & & 0.031 & 0.004 & & 0.003 \\
\hline College & 0.147 & $* * *$ & 0.041 & 0.013 & $* * *$ & 0.004 \\
\hline On-farm work (<30 days) & base group & & & & & \\
\hline On-farm work (30-59 days) & 0.114 & $* * *$ & 0.033 & 0.010 & $* * *$ & 0.003 \\
\hline On-farm work (60-89 days) & 0.126 & $* * *$ & 0.044 & 0.011 & $* * *$ & 0.004 \\
\hline On-farm work (90-149 days) & 0.179 & $* * *$ & 0.056 & 0.016 & $* * *$ & 0.006 \\
\hline On-farm work (150-179 days) & 0.214 & $* * *$ & 0.063 & 0.020 & $* * *$ & 0.007 \\
\hline On-farm work (180-249 days) & 0.135 & * & 0.077 & 0.012 & & 0.008 \\
\hline On-farm work (>249 days) & 0.318 & $* * *$ & 0.102 & 0.034 & ** & 0.014 \\
\hline \multicolumn{7}{|c|}{ Household members over 15 years old } \\
\hline FH_male & -0.025 & & 0.028 & -0.002 & & 0.002 \\
\hline FH_age (45-65) & 0.176 & $* * *$ & 0.035 & 0.014 & $* * *$ & 0.003 \\
\hline FH_age (65 and up) & 0.156 & $* * *$ & 0.060 & 0.013 & $* * *$ & 0.005 \\
\hline FH_junior & 0.008 & & 0.042 & 0.001 & & 0.003 \\
\hline FH_senior & 0.032 & & 0.055 & 0.003 & & 0.004 \\
\hline FH_college & 0.185 & $* *$ & 0.078 & 0.015 & $* *$ & 0.006 \\
\hline Working & -0.161 & $* * *$ & 0.033 & -0.013 & $* * *$ & 0.003 \\
\hline \multicolumn{7}{|l|}{ Farm characteristics } \\
\hline Land & 0.071 & $* * *$ & 0.010 & 0.006 & $* * *$ & 0.001 \\
\hline Labor & 0.008 & $* *$ & 0.004 & 0.001 & $* *$ & 0.000 \\
\hline cons & -2.002 & $* * *$ & 0.069 & & & \\
\hline
\end{tabular}

Note: ${ }^{*}{ }^{* *}$ and ${ }^{* * *}$ denote significant at the $10 \%, 5 \%$ and $1 \%$ significance level.

The results in Table 2 illustrate that the farmland size has a positive but decreasing effect on the probability of adoption. A plot of the estimated probability of organic farming adoption with the farmland area is presented in Figure 3 which portrays the inverted-U shape of the influence of farmland area on the adoption probability. As it is shown, farms with less than 50 hectares of farmland, the predicted probability is increasing with farm scale. Nevertheless, for the farms larger in size, ranging from 60 hectares to more than 150 hectares, increase in land size reduces the likelihood to adopt organic farming.

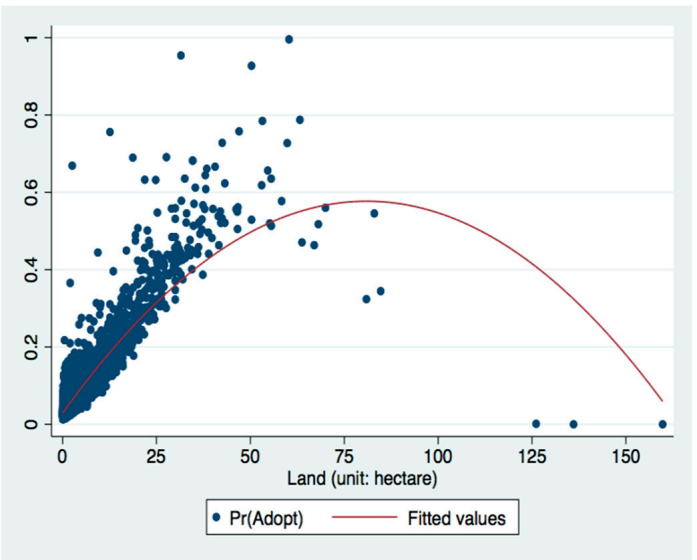

Figure 3. Predicted probability with respect to land size. 


\subsection{Comparing Full-Time and Part-Time Farmers}

A common rule to define part-time farming is working 150-200 days off the farm [21]. Based on this definition, principal operators who report more than 150 days of on-farm working days annually are categorized as the full-time farmers in this study. This categorization triggers another interesting question: Are the two groups different in the determinants of organic farming adoption? Using the categorizing rule, we divide the sample into two groups to examine the differences in the factors determining the adoption of organic farming. The results of the estimated coefficient and partial marginal effect at means are presented in Table 3.

Table 3. Probit estimation of full- and part- time households.

\begin{tabular}{|c|c|c|c|c|c|}
\hline \multirow[b]{2}{*}{ Variable } & \multicolumn{2}{|c|}{ Full-Time Household (obs = 18,273) } & \multicolumn{3}{|c|}{ Part-Time Household (obs $=195,261)$} \\
\hline & Marginal Effects & \multirow[t]{2}{*}{ Std. Err. } & \multicolumn{2}{|c|}{ Marginal Effects } & \multirow[t]{2}{*}{ Std. Err. } \\
\hline Principal operator & & & & & \\
\hline Male & 0.007 & 0.005 & -0.003 & & 0.002 \\
\hline Age (45-65) & -0.021 & 0.010 & 0.001 & & 0.003 \\
\hline Age (65 and up) & -0.008 & 0.012 & 0.005 & * & 0.003 \\
\hline Junior & 0.003 & 0.008 & -0.001 & & 0.002 \\
\hline Senior & 0.010 & 0.009 & 0.003 & & 0.003 \\
\hline College & 0.026 & 0.017 & 0.012 & $* * *$ & 0.004 \\
\hline On-farm work (<30 days) & & & Base group & & \\
\hline On-farm work (30-59 days) & & & 0.009 & $* * *$ & 0.003 \\
\hline On-farm work (60-89 days) & & & 0.009 & ** & 0.004 \\
\hline On-farm work (90-149 days) & & & 0.013 & $* *$ & 0.005 \\
\hline On-farm work (150-179 days) & Base group & & & & \\
\hline On-farm work (180-249 days) & -0.006 & 0.006 & & & \\
\hline On-farm work (>249 days) & 0.021 & 0.012 & & & \\
\hline \multicolumn{6}{|c|}{ Household members over 15 years old } \\
\hline FH_male & -0.011 & 0.008 & -0.001 & & 0.002 \\
\hline FH_age (45-65) & 0.031 & 0.011 & 0.012 & $* * *$ & 0.003 \\
\hline FH_age (65 and up) & 0.019 & 0.016 & 0.012 & $* *$ & 0.005 \\
\hline FH_junior & -0.005 & 0.012 & 0.001 & & 0.003 \\
\hline FH_senior & 0.009 & 0.013 & 0.002 & & 0.004 \\
\hline FH_college & 0.016 & 0.019 & 0.015 & $* *$ & 0.006 \\
\hline Working & -0.008 & 0.010 & -0.013 & $* * *$ & 0.003 \\
\hline \multicolumn{6}{|l|}{ Farm characteristics } \\
\hline Land & 0.004 & 0.001 & 0.009 & $* * *$ & 0.001 \\
\hline Landsq & -0.000 & 0.000 & -0.000 & $* * *$ & 0.000 \\
\hline Labor & 0.000 & 0.000 & 0.001 & $* *$ & 0.000 \\
\hline
\end{tabular}

Notes: ${ }^{* * *}$ and ${ }^{* * *}$ denote significant at the $10 \%, 5 \%$ and $1 \%$ significance level.

One interesting finding from the comparison of the adoption determinants is that female operators of the part-time farms are more likely to adopt organic farming while female operators of the full-time farms are not. The results suggest the presence of significant gender differences in rice farming may depend on the time principal operators devote to on-farm work. Some previous studies explained the gender difference in agricultural practices from the perspective of value orientations held by the female and the male [13] and the females' stronger bond with the nature [14]. The findings in this study partly support this observation. According to the results in Table 3, relative to the young operators, middle-aged operators of the full-time households are less likely to adopt organic farming. As for the part-time households, elder operators have a higher adoption probability relative to the young operators.

In general, both groups adoption probability increases with the principal operator's onfarm working days. The operator's college degrees are relevant only to part-time farmers, with 0.012 of marginal effect. A novel finding is that, the larger share of the members who are currently working in the part-time households, the probability of adopting organic 
farming is lower. This result is in line with previous research finding the significant influence of off-farm employment on the probability of adoption [24]. Similarly, number of hired labor significantly increases the adoption probability for the part-time households.

The land size is a significant determinant of the adoption probability for both fulland part-time households. For the part-time households, the magnitude of the marginal effect is more than twice of that of the full-time household. The squared terms are all significant as well. The curves showing the relation of land size and estimated adoption probability are plotted in Figure 4 which reveals a similar inverted-U shape which peaks at 80 hectares for both groups. However, the curvature of the curve for part-time farms is larger, suggesting the marginal effect of land size on the adoption probability is greater for the part-time households.

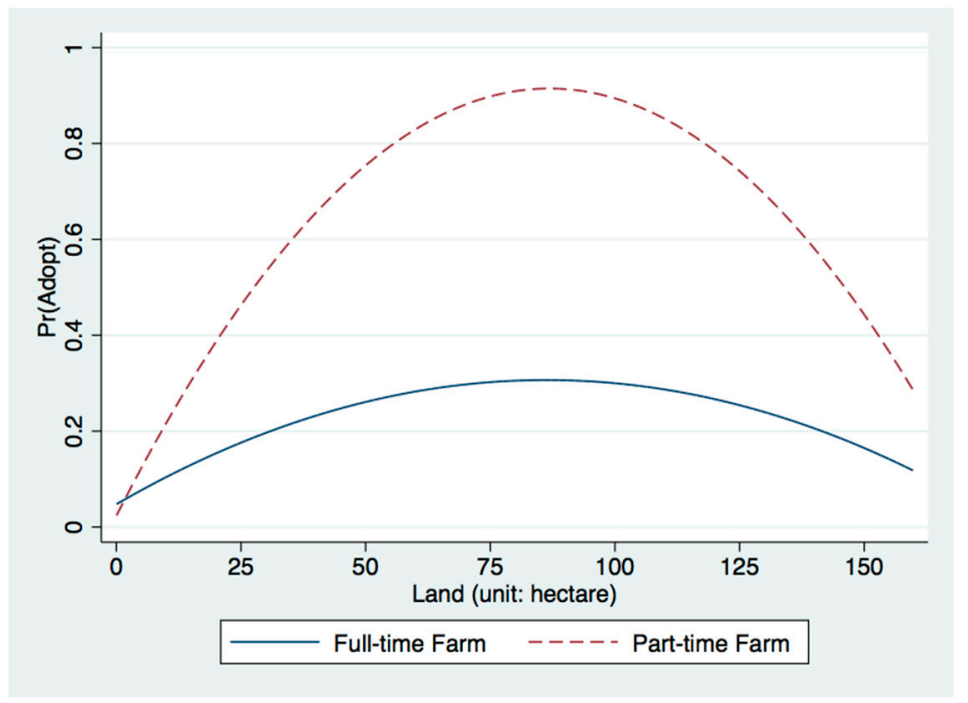

Figure 4. Predicted probability of full- and part- time farms with respect to land size.

\section{Discussion}

Our primary interest was to examine the determinants of organic farming adoption of rice farmers in Taiwan. The results reveal that the principal operator's characteristics, such as their devotion to farm activities reflected by on-farm working days, and household human capital related characteristics along with farm traits have significant effects on the adoption decision. It is notable that, taking diverse crop types or livestock sectors and different methods utilized into account, past studies did not reach a consensus in most of the variables considered in this study. Our result that elder farmers that aged 65 years old or older are more likely to adopt organic farming is in part consistent with some previous research, e.g., [12]. The result presented here is novel. Since organic farming is often regarded as more labor demanding for the time cost on crop management, elder farmers are considered less likely to adopt. We also find that the households with larger share of mid-aged or elders are more inclined to the adoption of organic farming. Taken together, in the present study, age is a significant driver to organic farming, similar to the finding in [10]. The insignificance of gender, however, is not consistent with some of the previous studies, e.g., $[7,9,10]$.

The result that on-farm work days have positive effects on organic farming adoption is consistent with the results reported in some earlier literature, e.g., [1,5,8]. One possible explanation for this result is that the farmers devoting more time to on-farm work may be more concerned with the negative effect of conventional farming on their health or on the environment. Although psychological factors such as environmental/health concern have been found to be a driver for the adoption of environmentally friendly practices [15], the data is not available in the agriculture census. However, the finding of the positive effect of on-farm working days can be taken to be some indication of farmers' environmen- 
tal/health concern since organic farming is considered more environmentally friendly than conventional farming.

It was found in the literature that farmers' off-farm work is one significant determinant of organic farming adoption [17-19]. In order to explore the differences in the adoption behavior between full- and part-time farmers, we categorize farm households into the two types. The results reveal that the determinants of organic farming adoption are diverse among full- and part-time households. It is found that, middle-aged full-time farmers have lower probability to adopt. This result may suggest that, for farmers who make living primarily on agricultural production, organic farming is not a promising alternative from the perspective of earning. Results concerning household member characteristics, nevertheless, have opposite effect from that of operators. The results connote that middle-aged family members in full-time farmer households may nudge principal operators towards organic farming. This result suggests the importance of opinion given to main operators by family members of the same generation, that is, brothers, sisters, or husbands and wives.

While some previous work, e.g., [24,25], did not find a significant effect of off-farm work on the adoption of organic farming, some studies found a positive association between off-farm income and organic adoption [26,27]. It was also pointed out in the previous work that off-farm income is critical to the adoption of new farming method [24]. This gives a possible explanation to the finding that part-time households hiring more labor have a higher probability to adopt organic farming. Since organic farming is more labor-demanding, part-time farm operators may need to hire workers to mitigate their burden on farm management.

Turning the spotlight to farm scale in the determination of organic farming adoption, our findings on farm size are not consistent with past studies. While farm size was found to be an insignificant determinant of organic farming $[3,24,28,29]$, it was found to have a positive impact in the present study. Furthermore, by dividing the rice households into full- and part-time households, the results indicate that the farm size has greater impact for part-time farm households (Figure 3). This result may reveal the variation in the degree of aversion towards agricultural production risks. Specifically, because part-time farmers have more diversified income sources, they may be less risk-averse towards production risks, and thus are more willing to take the risk of lower production in exchange of healthier living style or better environment. Analogously, full-time farmers may be more risk-averse, and therefore are less willing to adopt organic farming. Figures 3 and 4 show an inverted-U relation between the probability of organic farming adoption and farm size. Nevertheless, the few large farms pull the curve downward. This study retains those observations since these large farms have influential impacts on organic extension in Taiwan.

\section{Conclusions}

Our exploration of the differences in the adoption determinants between the partand full-time households contributes to the extant literature by narrowing the gap in understanding the association of farm management strategy and the adoption of organic farming. From the perspectives of policy design and agricultural extension, the present study also enables politicians and practitioners to gain understanding of the drivers and/or barriers of organic farming adoption.

Understanding the determinants of farmers' organic farming adoption has been an important issue in the last two decades. Previous studies on this issue tended to utilize relatively smaller data set with observations around or less than 600 [1]. The understanding of the determinants of adoption is thus limited in scope in comparison to large dataset, and inconclusive results were often reported. The data used in this study is taken from the national-level agriculture census. Therefore, the results found in the present study can provide significant complements to the literature on organic farming adoption. Furthermore, it is found that household-level human capital such as proportion of middleaged or elder members, and proportion of members with college degree, have significantly positive effect on the adoption probability. The results suggest that for outreaching organic 
farming, different projects can be designed according to farm households' characteristics in order to achieve the policy agenda.

Previous studies on determinants of organic farming adoption were often constrained by the dataset used. This study is no exception. Since the data used in this study is taken from the national-level agriculture census, data for the psychological factors related to the adoption behavior are not available. Therefore, one possible avenue for further research is to take into account the other attributes that may also affect the adoption decision, such as environmental concerns [15], positive/barrier attitude, norms and moral obligations [1].

Author Contributions: Conceptualization, Y.-H.L.; methodology, Y.-H.L.; software, Y.-C.C.; validation, Y.-H.L.; formal analysis, Y.-H.L., M.-H.T. and Y.-C.C.; investigation, Y.-H.L.; resources, Y.-H.L.; data curation, Y.-C.C. and T.-Y.Y.; writing—original draft preparation, M.-H.T., Y.-C.C. and Y.-H.L.; writing—review and editing, Y.-H.L.; visualization, Y.-C.C. and Y.-H.L.; supervision, Y.-H.L.; project administration, Y.-H.L.; funding acquisition, Y.-H.L. All authors have read and agreed to the published version of the manuscript.

Funding: Part of this research was funded by the Ministry of Technology and Science (MOST) in Taiwan, grant number: MOST-109-2410-H-002-112.

Data Availability Statement: The data used in this study was purchased from the Executive Yuan by the corresponding author.

Conflicts of Interest: The authors declare no conflict of interest.

\section{References}

1. Sapbamrer, R.; Thammachai, A. A systematic review of factors influencing farmers' adoption of organic farming. Sustainability 2021, 13, 3842. [CrossRef]

2. Burton, M.; Rigby, D.; Young, T. Analysis of the determinants of adoption of organic horticultural techniques in the UK. J. Agric. Econ. 1999, 50, 47-63. [CrossRef]

3. Burton, M.; Rigby, D.; Young, T. Modelling the adoption of organic horticultural technology in the UK using duration analysis. Aust. J. Agric. Econ. 2003, 47, 29-54. [CrossRef]

4. Koesling, M.; Flaten, O.; Lien, G. Factors influencing the conversion to organic farming in Norway. Int. J. Agric. Resour. Gov. Ecol. 2008, 7, 78-95. [CrossRef]

5. Kallas, Z.; Serra, T.; Gil, J.M. Farmers' objectives as determinants of organic farming adoption: The case of Catalonian vineyard production. Agric. Econ. 2010, 41, 409-423. [CrossRef]

6. Khaledi, M.; Weseen, S.; Sawyer, E.; Ferguson, S.; Gray, R. Factors influencing partial and complete adoption of organic farming practices in Saskatchewan, Canada. Can. J. Agric. Econ. 2010, 58, 37-56. [CrossRef]

7. Tiffin, R.; Balcombe, K. The determinants of technology adoption by UK farmers using Bayesian model averaging: The cases of organic production and computer usage. Aust. J. Agric. Econ. 2011, 55, 579-598. [CrossRef]

8. Uematsu, H.; Mishra, A.K. Organic farmers or conventional farmers: Where's the money? Ecol. Econ. 2012, 78, 55-62. [CrossRef]

9. Mala, Z.; Malý, M. The determinants of adopting organic farming practices: A case study in the Czech Republic. Agric. Econ. 2013, 59, 19-28. [CrossRef]

10. Sodjinou, E.; Glin, L.C.; Nicolay, G.; Tovignan, S.; Hinvi, J. Socioeconomic determinants of organic cotton adoption in Benin, West Africa. Agric. Food Econ. 2015, 3, 12. [CrossRef]

11. Kamau, J.W.; Stellmacher, T.; Biber-Freudenberger, L.; Borgemeister, C. Organic and conventional agriculture in Kenya: A typology of smallholder farms in Kajiado and Murang'a counties. J. Rural Stud. 2018, 57, 171-185. [CrossRef]

12. Serebrennikov, D.; Thorne, F.; Kallas, Z.; McCarthy, S.N. Factors Influencing adoption of sustainable farming practices in Europe: A systemic review of empirical literature. Sustainability 2020, 12, 9719. [CrossRef]

13. Bjørkhaug, H. Is there a female principle in organic farming? An interpretation of data for Norway. In Sociological Perspectives of Organic Agriculture: From Pioneer to Policy; Holt, G.C., Reed, M., Eds.; CABI: Wallingford, UK, 2006; pp. 195-209.

14. Modelmog, I. 'Nature'as a Promise of Happiness: Farmers' Wives in the Area of Ammerland, Germany. Sociol. Rural. 1998, 38, 109-122. [CrossRef]

15. Luh, Y.-H.; Tsai, M.-H.; Fang, C.-L. Do first-movers in the organic market stand to gain? Implications for promoting cleaner production alternatives. J. Clean. Prod. 2020, 262, 121156. [CrossRef]

16. The Growth Trend of Organic Planting and Friendly Farming Area in Taiwan from 1999 to 2020. Available online: https: / / www.oapc.org.tw/en/english-serve/ (accessed on 2 September 2021).

17. Fernandez-Cornejo, J.; Hendricks, C.; Mishra, A. Technology adoption and off-farm household income: The cas of herbicidetolerant soybeans. J. Agric. App. Econ. 2005, 36, 549-563. [CrossRef]

18. Gedikoglu, H.; McCann, L.; Artz, G. Off-farm employment effects on adoption of nutrient management practices. Agric. Res. Econ. Rev. 2011, 40, 293-306. [CrossRef] 
19. López, C.P.; Raquena, J.C. Factors related to the adoption of organic farming in Spanish olive orchards. Spanish J. Agric. Res. 2005, 3, 5-16. [CrossRef]

20. Fernandez-Cornejo, J.; Mishra, A.K.; Nehring, R.F.; Hendricks, C.; Southern, M.; Gregory, A. Off-farm income, technology adoption, and farm economic performance. Econ. Res. Rep. 2007, 36. [CrossRef]

21. Johanns, A.M.; Leibold, K. Getting Started in Farming: Part-Time or Small Farms. Ag Decision Maker 2020, C4-09, 1-6.

22. Egan, K.J.; Herriges, J.A.; Kling, C.L.; Downing, J.A. Valuing water quality as a function of water quality measures. Am. J. Agric. Econ. 2009, 91, 106-123. [CrossRef]

23. Greene, W.H. Models for Discrete Choice. In Econometric Analysis, 5th ed.; Greene, W.H., Ed.; Prentice Hall: Hoboken, NJ, USA, 2002; pp. 663-755.

24. Pornpratansombat, P.; Bauer, B.; Boland, H. The adoption of organic rice farming in Northeastern Thailand. J. Org. Syst. 2011, 6, $4-12$.

25. Wollni, M.; Lee, D.R.; Thies, J.E. Conservation agriculture, organic marketing, and collective action in the Honduran hillsides. Agric. Econ. 2010, 41, 373-384. [CrossRef]

26. Genius, M.; Pantzios, C.J.; Tzouvelekas, V. Information acquisition and adoption of organic farming practices. J. Agric. Resour. Econ. 2006, 31, 93-113.

27. Sriwichailamphan, T.; Sucharidtham, T. Factors affecting adoption of vegetable growing using organic system: A case study of Royal Project Foundation, Thailand. Int. J. Econ. Manag. Sci 2014, 3, 2. [CrossRef]

28. Läpple, D.; Kelley, H. Spatial dependence in the adoption of organic drystock farming in Ireland. Eur. Rev. Agric. Econ. 2015, 42, 315-337. [CrossRef]

29. Hattam, C.E.; Lacombe, D.J.; Holloway, G.J. Organic certification, export market access and the impacts of policy: Bayesian estimation of avocado smallholder "times-to-organic certification" in Michoacán Mexico. Agric. Econ. 2012, 43, 441-457. [CrossRef] 